\title{
A IGREJA COMO COMUNIDADE EVANGELIZADORA EM BUSCA DA UNIDADE
}

\author{
The ChuRch as Evangelizing COMmunity IN SEARCH OF UNITY
}

\author{
Geraldo Luiz Borges Hackmann* \\ Tiago de Fraga Gomes**
}

\section{RESUMO}

A idealização da comunidade cristã em Atos dos Apóstolos enfatiza alguns elementos fundamentais da Igreja primitiva: a perseverança no ensinamento dos apóstolos, a comunhão fraterna, a partilha e a vida espiritual. O Concílio Vaticano II objetivou um aggiornamento da Igreja em vista das novas necessidades pastorais. Levou a termo a tarefa de definir a natureza da Igreja na nova situação histórica emergente. A Lumen Gentium e a Gaudium et Spes são constituições conciliares de fundamental importância na renovação da autoconsciência da Igreja. A Igreja enquanto comunidade que escuta e anuncia a Palavra de Deus, tem a grande missão de evangelizar. É fundamental evangelizar com inteligência, levando a mensagem de Cristo a todos os povos. A missão é ecumênica, pois se destina a toda a humanidade. A diversidade e a variedade enriquecem a humanidade.

Palavras-chave: Igreja. Comunidade. Evangelização. Missão. Ecumenismo.

\section{ABSTRACT}

The idealization of the Christian community in Acts emphasizes some key elements of the early Church: perseverance in the apostles' teaching, to fellowship, sharing and spiritual life. The Second Vatican Council aimed a church aggiornamento in view of the new pastoral needs. Brought to fulfillment the task

* Doutor em Teologia, professor da Escola de Humanidades da Pontifícia Universidade Católica do Rio Grande do Sul (PUCRS), nos cursos de graduação e pós-graduação em Teologia.

** Mestre em Teologia pela Pontifícia Universidade Católica do Rio Grande do Sul (PUCRS).

\begin{tabular}{|l|l|l|l|l|l|}
\hline Teocomunicação & Porto Alegre & v. 45 & n. 3 & p. 285-307 & set.-dez. 2015 \\
\hline
\end{tabular}


of defining the Church's nature in the emerging new historical situation. The Lumen Gentium and Gaudium et Spes conciliar constitutions are of fundamental importance in the Church's self-renewal. The Church as a community that listens to and proclaims the Word of God, has the great mission of evangelizing. It is essential evangelize intelligently, taking the message of Christ to all peoples. The mission is ecumenical because it is intended for all mankind. The diversity and variety enrich mankind.

Keywords: Church. Community. Evangelization. Mission. Ecumenism.

\section{Fundamentação bíblica: a idealização da comunidade cristã em At 2,42-47}

O livro dos Atos dos Apóstolos pode ser lido como "uma narrativa da ação do Espírito Santo no início da vida da Igreja". Prescindindo de toda ingenuidade, não se pode interpretar literalmente tudo o que é descrito nesse livro como se fosse exatamente correspondente à realidade histórica ${ }^{2}$. "Trata-se naturalmente de uma visão idealizada da vida da comunidade", um relato teológico carregado de significados e cheio de pertinência para a eclesiologia atual, uma "idealização, que consiste em considerar os primeiros tempos do cristianismo como paradigma"4. Através desse relato, é possível proceder à busca de elementos paradigmáticos da identidade cristã, por uma aproximação do que representou o movimento pós-pascal dos seguidores

1 HACKMANN, G. L. B. A Igreja nos Atos dos Apóstolos, p. 427. O livro de Atos dos Apóstolos narra os efeitos de Pentecostes, dando-nos uma descrição da Igreja cheia do Espírito Santo. A respeito desse assunto ver também: STOTT, J. R. W. A mensagem de Atos, p. 86-93.

2 A respeito do gênero literário do livro dos Atos dos Apóstolos, afirma WEGNER, U. Exegese do Novo Testamento, p. 182: “À semelhança dos evangelhos, também o gênero dos 'Atos dos Apóstolos' apresenta características singulares em relação à literatura da época. Há, é verdade, algumas semelhanças entre essa obra e outras narrativas de atos

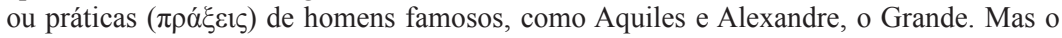
caráter de testemunho e de conclamação à fé que perpassa essa narrativa sobre os atos dos apóstolos é singular dentro do gênero das 'práticas' narradas na Antiguidade".

3 COMBLIN, J. Atos dos Apóstolos, p. 105. Pode constatar-se o seguinte em INICIAÇÃO À BÍBLIA. Para você estudar o Novo Testamento, p. 22: "No início dos Atos dos Apóstolos, o autor nos apresenta o retrato idealizado da comunidade primitiva em Jerusalém. Ele se esforça em salientar os traços que lhe parecem essenciais, em pequenos resumos que chamamos sumários".

4 HACKMANN, G. L. B. op. cit., p. 427. 
de Jesus ${ }^{5}$. Essa idealização "projeta o modelo comunitário, fazendo uma síntese do melhor que houve nas comunidades dos anos 30 a 60 d.C.".; aponta para um modelo de comunidade, um sonho a ser compartilhado e vivido na concretude de cada circunstância.

$\mathrm{O}$ retrato favorecido da primeira comunidade em Jerusalém, de sua unanimidade $(2,46 ; 4,32 ; 5,12)$, de sua comunhão de bens $(2,44 \mathrm{~s} . ; 4,32-37)$, de sua fulgurante progressão numérica $(2,41$; $4,4 ; 5,14 ; 6,7)$, levanta uma suspeita de idealização em Lucas. Não é de duvidar que, aos olhos do autor, os primeiros tempos da cristandade agrupada em torno dos Doze constituem uma 'idade de ouro' excepcional e, como tal, um modelo para os leitores. À semelhança de Gênesis 1-11, a "história das origens" funciona em Atos 1-6 como um mito fundador para uma cristandade que no tempo de Lucas está dividida e separada do Judaísmo?

O modelo de comunidade cristã idealizado por Atos dos Apóstolos enfatiza alguns elementos fundamentais da Igreja primitiva: "Eram perseverantes no ensinamento dos apóstolos, na comunhão fraterna, na fração do pão e nas orações" (At 2, 42). O ensinamento dos apóstolos (didaché) corresponde ao Evangelho testemunhado por aqueles que conviveram com Jesus durante a sua vida terrena e que presenciaram os seus atos. Corresponde à vida e prática de Jesus, sua pessoa e seu projeto, como fundamento de toda a atividade evangelizadora da comunidade eclesial. A tradição apostólica ${ }^{8}$ interpela a vida concreta dos cristãos, sugerindo fidelidade e perseverança na Palavra de Deus. A comunhão ${ }^{9}$

5 "Nós somos sempre confrontados com uma multiplicidade de testemunhos diversos sobre a vida, os gestos e as palavras de Jesus que vão ser relidos pela primeira comunidade cristã à luz do evento pascal. A tarefa da exegese, mas também da teologia, seria justamente tomar a sério esta relatividade histórica dentro do cânon das Escrituras" (GEFFRÉ, C. Crer e interpretar, p. 49).

6 MOSCONI, L. Atos dos Apóstolos, p. 121.

7 MARGUERAT, D. Os Atos dos Apóstolos, p. 156-157.

8 Como afirma Ratzinger, "a comunidade, nascida da mensagem evangélica, é convocada pela palavra daqueles que foram os primeiros a conhecer o Senhor e foram enviados por Ele. Ela sabe que pode contar com a orientação dos Doze, assim como a daqueles que se unem progressivamente como seus sucessores no ministério da Palavra e na entrega à comunhão" (RATZINGER, J. Os apóstolos e os primeiros discípulos de Cristo, p. 33).

9 Ratzinger afirma que "a comunhão nasce da fé derivada da pregação apostólica, se alimenta de dividir o pão e da oração e se expressa na caridade fraterna e na entrega. Estamos diante de uma descrição da comunhão da Igreja nascente com toda a riqueza de 
representa o modo de viver da comunidade, a qual opta pelos mesmos sentimentos e opções de Jesus. Uma comunhão radical que se expressa em uma solidariedade extrema, fruto de uma profunda espiritualidade eucarística. A experiência da comunhão (koinonía) torna a pessoa generosa $(\text { koinonikos })^{10}$. A comunhão cristã é uma atitude voluntária de cuidado, que leva a compartilhar sentimentos e a se envolver em ações transformadoras.

Este compêndio das principais normas da vida da Igreja a serem observadas pelos recém batizados provavelmente reflete a época de Lucas. O seu retrato da primeira comunidade como um grupo que persevera em todas essas normas (proskarterountes) inicia o padrão de idealização que marca todos os resumos e atesta a distância do autor em relação a seu assunto ${ }^{11}$.

Não é possível formular uma eclesiologia sistemática que responda aos anseios da realidade atual com seus apelos e questionamentos, tendo como base apenas elementos de uma eclesiologia narrativa, sem um discernimento crítico a respeito do contexto sócio-histórico-cultural da época. A partir dos elementos advindos dessa experiência narrada, desmitologizando toda idealização, sem acabar com a axiologia inerente ao modelo em questão, é possível resgatar algumas das motivações que impulsionaram os primeiros cristãos a formarem comunidade a partir da fé em Jesus Cristo, sob a ação do Espírito Santo.

O livro escrito por Lucas oferece uma narração, ou seja, uma descrição dos primeiros anos de vida da Igreja, abarcando o período apostólico, que vai dos anos 30 a 70, aproximadamente. Assim, o autor reconstitui o movimento de Jesus no período que abrange o tempo após a ressurreição e antes da organização da Igreja. A situação da Igreja narrada em Atos, escrito por volta dos anos 70 e 80 , retrata a época em que a Igreja não está organizada, pois a comunidade eclesial vai passar pelo processo de estruturação mais tarde, por volta do primeiro século e início do seguinte ${ }^{12}$.

seus dinamismos internos e de suas expressões visíveis: o dom da comunhão é custodiado e promovido especialmente pelo ministério apostólico, que é, por sua vez, um dom para toda a comunidade" (Ibid., p. 25).

${ }^{10}$ Cf. STOTT, J. R. W. op. cit., p. 88.

${ }^{11}$ BROWN, R. E.; FITZMYER, J. A.; MURPHY, R. E. (Eds.). Novo comentário bíblico São Jerônimo, p. 333.

${ }^{12}$ HACKMANN, G. L. B. op. cit., p. 428-429. 
O ideal de vida comunitária descrito por Atos dos Apóstolos se caracteriza pelo desprendimento, a partilha dos bens e a fraternidade, não havendo necessitados entre eles, o que dá a entender que o enfoque de sua abordagem sublinha a dimensão antropológico-social da mensagem cristã. "Todos os fiéis estavam unidos e tinham tudo em comum; vendiam tanto as propriedades quanto os bens e repartiam entre todos, conforme a necessidade de cada um" (At 2,44-45). Não se trata apenas de disposições interiores puramente sentimentais, a comunhão de bens é material, e supõe que os mais ricos repartam seus bens com os mais pobres. É uma comunhão profética que aponta para a necessidade do restabelecimento da dignidade humana fundamental comum a todos ${ }^{13}$.

O Evangelho influi profundamente na vida social, transformando a vida dos cristãos. Estes se tornam um testemunho credível diante da sociedade, ao ponto do seu número crescer e serem estimados pelo povo (cf. At 2,47). "A novidade cristã é a comunhão entre ricos e pobres"14. Essa é a solução proposta por Atos dos Apóstolos para que se realizem as promessas do Evangelho de Jesus na vida concreta das pessoas, através de uma conversão integral que influi na totalidade da existência, unindo fé e vida. A redistribuição dos bens é um questionamento à sociedade vigente, e constitui um "fermento de contestação da legitimidade dos sistemas de propriedade" ${ }^{15}$ responsáveis pela desigualdade. A comunhão é uma resposta ao antigo drama da divisão, ao mesmo tempo em que se coloca como um desafio, como uma provocação para uma mudança radical, fruto da fé em Jesus.

Inseridos na sociedade de seu tempo, podemos afirmar sem anacronismos que, embora os cristãos pautassem as suas atitudes pelas exigências do Evangelho, o seu comportamento na sociedade civil não poderia ser considerado extremamente dicotômico em relação aos seus contemporâneos. O Evangelho "muda mais o espírito de que o tecido

${ }^{13}$ Como no tempo dos Atos dos Apóstolos, o mundo atual, caracterizado pelo conhecimento e pela informação, lança alguns desafios para a evangelização, em um contexto de progresso científico e de inovações tecnológicas com aplicações diversas em nossa vida. É possível perceber que há uma crise antropológica em uma economia de exclusão e de desigualdade social, onde impera a cultura do descartável e da "globalização da indiferença" (EG 54). Estamos anestesiados pelo bem-estar. "A ambição do poder e do ter não conhece limites" ( $E G 56)$ no âmbito do mercado divinizado, onde "os mecanismos da economia atual promovem uma exacerbação do consumo" ( $E G 60)$, criando uma mentalidade adversa a um desenvolvimento sustentável.

${ }^{14}$ COMBLIN, J. op. cit., p. 105.

${ }^{15}$ Ibid., p. 106. 
diário da vida"16. Os cristãos levavam a vida cotidiana das pessoas de seu tempo. O grande diferencial foi a mudança de mentalidade expressa no testemunho de vida comunitária.

A atitude de fé das primeiras comunidades, que se reuniam em torno da mesa para a partilha e a oração, vai afetando o cotidiano daqueles que aderiam à mesma fé em Jesus Cristo. "Dia após dia, perseveravam unânimes no Templo, partiam o pão de casa em casa, partilhavam as refeições com alegria e simplicidade de coração" (At 2, 46). O testemunho de fé dos cristãos vai chamar a atenção para a novidade que o Evangelho propõe, constituindo-se numa apologia viva que vai atrair cada vez mais adeptos. "A comunidade dá a impressão de conquistar o povo inteiro, o que confirma que ela representa o verdadeiro Israel" 17 . Assim, a proposta de Jesus se coloca em continuidade com as grandes promessas veterotestamentárias, e a comunhão eclesial é testemunho profético disso.

O Espírito Santo impulsiona a Igreja a evangelizar. "O Espírito Santo é um Espírito missionário que criou uma Igreja missionária"18. Os Atos dos Apóstolos narram a expansão da Palavra de Deus pela irradiação do testemunho de vida da comunidade cristã. "A evangelização não era uma atividade ocasional ou esporádica da Igreja primitiva"19, fazia parte do seu cotidiano, da sua vida diária, pelo transbordamento natural de corações cheios do Espírito Santo na comunhão perseverante com Deus e com os irmãos e irmãs na fé.

\section{Fundamentação dogmática: a Igreja a partir da Lumen Gentium e da Gaudium et Spes}

O Concílio Vaticano II, em sua volta às origens da fé, teve um caráter eminentemente pastoral-eclesiológico. Seu objetivo foi apresentar a mensagem cristã tradicional de forma mais adequada à contemporaneidade, com novos métodos de evangelização e apostolado, numa maior abertura dialógica e fraterna com o mundo ${ }^{20}$. "Foi o Concílio

\footnotetext{
${ }^{16}$ HAMMAN, A. G. A vida cotidiana dos primeiros cristãos (95-197), p. 47.

${ }^{17}$ COMBLIN, J. op. cit., p. 108.

${ }^{18}$ STOTT, J. R. W. op. cit., p. 91.

${ }^{19}$ Ibid., p. 92.

${ }^{20}$ Cf. GOMES, T. F. A eclesiologia conciliar e a sua recepção na América Latina, p. 15. No dizer de Beozzo, "o Concílio Vaticano II significou, para a Igreja Católica, um divisor de águas, o fim de uma época e o início de outra, pois encerrou, de certo modo, a longa fase inaugurada com o Concílio de Trento (1545-1563), fase de ruptura com o nascente mundo
} 
da autoconsciência, da clarificação, da compreensão e do diálogo"21 cuja intenção foi tornar a Igreja presente e atuante no mundo, com uma voz mais sensível à razão e ao coração do homem do século XX. O Concílio Vaticano II impulsionou o diálogo da Igreja com o mundo atual ${ }^{22}$. O estratégico questionamento foi o seguinte: como evangelizar no mundo de hoje?

O Vaticano II é sobretudo um Concílio que se distingue muito mais pelo novo espírito, que pelas novas explicações da doutrina cristã. Não faltam, é certo, novas explicações (por exemplo sobre a Igreja, o episcopado, o presbiterado, a Tradição, a liberdade religiosa, etc.), mas o especificamente novo e importante do XXI Concílio Ecumênico está na sua atitude pastoral, ecumênica e missionária perante o mundo de hoje; no seu espírito de abertura a novos valores; na sua disposição de dialogar e até cooperar com os não-católicos, os não-cristãos e os não crentes; no seu clima de compreensão dos outros; na sua conviç̧ão de ser apenas o sinal, o instrumento ou o sacramento (mysterium) do Senhor Glorificado 23.

Duas palavras-chave ajudam a compreender a pastoral e a eclesiologia do Concílio Vaticano II: aggiornamento e diálogo. "A transformação tende a adaptar a Igreja aos tempos atuais e a preparar a unidade. [...] Saímos de uma estrutura de defesa e entramos numa estrutura de diálogo"24. Isso mostra uma Igreja disposta a se atualizar e a se renovar. A Igreja, em sua historicidade, busca se encarnar, sempre atenta aos sinais dos tempos, em uma abertura crítica ao mundo contemporâneo, tendo sempre o Evangelho como critério basilar de sua ação e atualização.

O relevo hermêutico do aggiornamento, malgrado a dificuldade de uma rigorosa determinação do termo, está estritamente conexo com a pastoralidade. O termo aggiornamento foi interpretado como reforma, mas com ele se queria indicar antes disponibilidade

moderno e de confronto com as correntes espirituais, culturais e políticas que emergiram do conjunto da renascença e, de modo particular, da reforma protestante.” (BEOZZO, J. O. Presença e atuação dos bispos brasileiros no Vaticano II, p. 125).

${ }^{21}$ SANTOS, M. A. Quarenta anos depois do Concílio Vaticano II. In: SANTOS, M. A. (Org.). Concílio Vaticano II, p. 13.

${ }^{22}$ Cf. KASPER, W. A Igreja católica, p. 402.

${ }^{23}$ KLOPPENBURG, B. A Eclesiologia do Vaticano II, p. 16.

${ }^{24}$ SOUZA, L. G. Do Vaticano II a um novo Concílio?, p. 246-247. 
e atitude para a busca, um compromisso global de uma renovada inculturação da revelação nas novas culturas. Desta forma, João XXIII teve a intenção de situar o Concílio na perspectiva da resposta cristã às instâncias de uma humanidade em vias de renovação profunda e global, talvez mais evidente hoje do que na época do Vaticano II, ao ser anunciado. O aggiornamento mostra-se como a indicação sintética da direção na qual o Concílio teria devido abrir o caminho à Igreja. Não se tratava de uma reforma institucional nem de uma modificação doutrinal, mas de uma imersão total na tradição, dirigida a um rejuvenescimento da vida cristã e da Igreja. Uma fórmula em que a fidelidade à Tradição e a renovação profética estavam destinadas a conjugar-se; a leitura dos sinais dos tempos devia entrar em sinergia recíproca com o testemunho do anúncio evangélico. Por sua parte, a assembleia conciliar compartilhou e fez próprio este objetivo. Tem-se inclusive a impressão de que a maioria se tivesse aglutinado justamente em torno da instância do aggiornamento ${ }^{25}$.

O Concílio Vaticano II objetivou um aggiornamento da Igreja em vista das novas necessidades pastorais. Levou a termo a tarefa de compreender a natureza da Igreja de maneira nova na situação histórica do século $\mathrm{XX}^{26}$. A Lumen Gentium e a Gaudium et Spes são constituições conciliares de fundamental importância na renovação da autoconsciência da Igreja. Na Lumen Gentium a Igreja reflete sobre si mesma, aprofundando a sua identidade. Na Gaudium et Spes a Igreja dialoga com o mundo hodierno, desinstalando-se de sua zona de conforto, admitindo a novidade ${ }^{27}$. São dois momentos diferentes que compõem

${ }_{25}$ ALBERIGO, G. Transizione epocale, p. 42.

${ }^{26}$ O Concílio Vaticano II colocou a Igreja em diálogo com o mundo moderno. Como afirma Souza, "dentro do processo histórico que foi sendo gestado, vão sendo colocados os pilares do diálogo com a modernidade. Esse diálogo terá seu evento maior no Vaticano II, Concílio da modernidade, o qual teve a arte de reconciliar a Igreja católica com o mundo moderno." (SOUZA, N. Contexto e desenvolvimento histórico do Concílio Vaticano II, p. 23). Vários movimentos de renovação, que propiciaram uma atitude de "volta às fontes" da identidade cristã, foram responsáveis pelos preparativos desse grande evento eclesial. Entre eles podemos citar o movimento litúrgico, o progresso nos estudos exegéticos em contato com as ciências arqueológicas, o reencontro com os Santos Padres, o diálogo com o existencialismo moderno e a filosofia fenomenológica, enfim, toda a postura de conciliação entre fé e ciência que proporcionou uma atitude dialógica da Igreja frente à modernidade.

${ }^{27}$ Segundo Madrigal, o Cardeal Suenens havia chegado à constatação de que "o anúncio do Concílio fez nascer grandes esperanças entre os fiéis e no mundo. Satisfazer esta dupla expectativa exige tratar uma dupla série de questões: 'uma primeira série versaria sobre a Igreja ad extra, ou seja, sobre a Igreja frente ao mundo de hoje'. 'Uma segunda série versaria sobre a Igreja ad intra, ou seja, sobre a Igreja em sim mesma, em vistas, por outra parte, a ajudá-la a responder melhor a sua missão no mundo"” (MADRIGAL, S. Vaticano II, p. 22). 
um mesmo movimento eclesiológico, tendo como consequência o surgimento de uma nova era eclesial.

$\mathrm{Na}$ Lumen Gentium "encontra-se uma nova consciência da Igreja, que supera a auto-suficiência de uma Igreja que se entende como fim em si mesma, e se descobre como a Igreja de Deus, que deve ser sacramento de salvação para o mundo" 28 . Com o Concílio Vaticano II, passa-se de uma eclesiologia da sociedade perfeita (societas perfecta) para uma eclesiologia trinitária, cristocêntrica e pneumatológica. A Igreja passa a se compreender como originária do mistério de Deus com a missão de testemunhá-lo ao mundo.

Na Igreja, sacramento de salvação (cf. $L G$ 1), "está presente o mistério do desígnio salvífico de Deus para a humanidade" ${ }^{29}$. A Igreja não existe por si mesma, mas deve ser o instrumento de Deus, só assim produzirá frutos. Nesse sentido, "a Lumen Gentium significa a superação de uma eclesiologia jurídica" ${ }^{30}$ que pensa a Igreja a partir de si mesma em sua horizontalidade imanente, para compreendê-la a partir de sua verticalidade e transcendência, isto é, a partir de Deus e de sua presença nela.

A Igreja toma consciência que a sua missão no mundo não é anunciar a si mesma, mas sim, evangelizar (cf. EN 14) a partir de sua comunhão com Deus. O Sínodo Extraordinário dos Bispos de 1985 destacou a ideia de comunhão como "síntese dos elementos essenciais da eclesiologia conciliar" ${ }^{31}$. A Igreja como sinal e instrumento do Reino de Deus, tem a missão de anunciá-lo e estabelecê-lo em todo o mundo (cf. $L G 5$ ). Ela é o Povo de Deus em busca de santidade (Ecclesia semper purificanda) que avança para a casa do Pai nos caminhos da história.

A Lumen Gentium apresenta Maria como imagem da Igreja. "A Igreja é virgem e mãe, concebida sem pecado e carrega o peso da história, e já possui uma dimensão escatológica. A Igreja é antecipada em Maria. Ela é a Igreja já realizada, ou ela é aquilo que a Igreja deverá ser um dia, quando terminar seu percurso na terra" ${ }^{32}$. Se espelhando na figura de Maria como um modelo fiel do discipulado e da comunhão com o plano salvífico de Deus, a Igreja é chamada à perfeição e à santidade para ser sinal de Deus no mundo.

\footnotetext{
${ }^{28}$ HACKMANN, G. L. B. A Igreja da Lumen Gentium e a Igreja da Gaudium et Spes, p. 662.

${ }^{29}$ Ibid., p. 663.

${ }^{30}$ Ibid., p. 664.

${ }^{31}$ Id. loc. cit.

${ }^{32}$ Ibid., p. 667.
} 
A preocupação da Gaudium et Spes é a de corresponder às exigências da missão evangelizadora da Igreja no mundo atual, assumindo uma postura de diálogo. A eclesiologia presente na Gaudium et Spes acompanha o desenvolvimento dos debates em torno da Lumen Gentium, especialmente no que diz respeito às relações entre a Igreja e a história. "Dentro dessa relação com a história é que se pode perceber a relação entre eclesiologia e doutrina social cristã" ${ }^{33}$. Partindo dos princípios da Revelação, a Igreja se sente interpelada a se pronunciar a respeito dos apelos de uma complexa problemática social. A Igreja pretende ouvir "as alegrias e as esperanças, as tristezas e as angústias dos homens de hoje, sobretudo dos pobres e de todos aqueles que sofrem" ( $G S 1)$, deixando que essas realidades ecoem em seu coração.

A consciência da relação da Igreja com o mistério trinitário "descortina uma perspectiva nitidamente histórico-salvífica" ${ }^{34}$, comprometendo a Igreja na transformação das realidades terrenas à luz do desígnio salvífico de Deus. "Na Gaudium et Spes, a Igreja entra em diálogo e comunhão ativa com o mundo" 35 , numa atitude de aggiornamento, atenta aos sinais dos tempos, com o intuito de recapitular a história humana, reconduzindo-a a sua fonte verdadeira. A Igreja está a serviço da salvação do mundo "para que Deus seja tudo em todos" (1 Cor 15,28), universalizando o dinamismo da comunhão. O Concílio Vaticano II produziu alguns deslocamentos fundamentais de significado, que em seu conjunto, revelam um novo pensar eclesiológico, onde o horizonte último é o mistério:

De uma Igreja-instituição para uma Igreja-sacramento; de uma Igreja voltada para si para uma Igreja voltada para o mundo; de uma Igreja sociedade corporativa para uma Igreja comunial e colegial; [...] de uma visão apologética para uma visão ecumênica, dialógica; de uma Igreja lugar de salvação para uma Igreja sacramento/ sinal de salvação; da instituição, do juridicismo para o carisma, a autenticidade; [...] do Magistério como cátedra da verdade para o sensus fidelium; das tradições para a Tradição; da Lei para o Evangelho, a caridade; da Autoridade para a Liberdade dos filhos de Deus; da Cúpula, do clero para a base, os leigos; do Centro, da centralização para a periferia, a colegialidade; da essência da Igreja para a pluralidade de imagens; da Igreja universal para as Igrejas particulares; do dogma para a pastoral; da verdade objetiva para a

\footnotetext{
${ }^{33}$ Ibid., p. 671.

${ }^{34}$ Ibid., p. 674.

${ }^{35}$ Id. loc. cit.
} 
vivência, a autenticidade, a veracidade; [...] do eclesiocentrismo para o reinocentrismo; da Igreja sempre a mesma para a Igreja sempre a reformar-se, em devir; [...] da Igreja-fuga mundi para a Igreja-inserção nas realidades terrestres; [...] da Igreja uniforme para a Igreja pluralista; da Igreja da identidade para a Igreja da diferença; da Igreja distante para a Igreja solidária com o mundo ${ }^{36}$.

O aprofundamento da identidade e da vocação da Igreja, a partir das reflexões que se seguem ao Concílio Vaticano II, configura uma nova compreensão de Igreja como mistério-sacramento de salvação para a humanidade. "Para a maioria dos católicos, as iniciativas postas em marcha pelo Concílio pertencem ao dia-a-dia da Igreja" ${ }^{37}$. Convém propagar entre as gerações atuais a riqueza que significou tal evento para o amadurecimento da identidade eclesial, despertando para a consciência de que ainda é preciso empreender muitos esforços para colocarmos em prática todas as decisões conciliares a respeito da missão da Igreja no mundo de hoje.

\section{Fundamentação antropológica, missiológica e ecumênica: o anúncio da Palavra de Deus no mundo atual}

\subsection{Anunciar a Palavra de Deus na palavra humana}

Ecoa no coração dos cristãos "as alegrias e as esperanças, as tristezas e as angústias dos homens de hoje" (GS 1). O empenho cristão em continuar a obra de Jesus Cristo, que veio ao mundo "para dar testemunho da verdade" ( $\left.J_{o} 18,37\right)$, se realiza pela hermenêutica da alteridade, da inculturação e do testemunho. A língua enquanto sistema de sinais que serve à comunicação humana é o canal da atividade comunicacional. Na dinâmica de Pentecostes, em que "todos ficaram repletos do Espírito Santo e começaram a falar em outras línguas" (At 2,4), a Igreja deve anunciar a Palavra de Deus em todas as línguas do mundo, indo ao encontro de todas as culturas, para falar aos homens de hoje. É preciso anunciar em todas as línguas as maravilhas de Deus (cf. At 2,11), rompendo com arcaísmos e estereótipos linguísticos ${ }^{38}$.

${ }^{36}$ LIBANIO, J. B. Concilio Vaticano II, p. 145-146.

${ }^{37}$ KASPER, W. Renovación a partir del origen, p. 58.

38 Para anunciarmos a Palavra de Deus no mundo atual com eficácia, "é preciso discernir entre as estruturas constantes da mensagem cristã fundamental e os esquemas de pensamento contingentes advindos das culturas." (GOMES, T. F. Hermenêutica teológica e teologia da revelação em Claude Geffré, p. 55). Para responder aos questionamentos contemporâneos à fé, é de fundamental importância compreender os códigos linguísticos e os idioletos convencionais em curso nos meios em que se veicula a linguagem teológica. 
Não se pode limitar a experiência de Deus a um sistema linguístico fechado. Diz Wittgenstein que "os limites de minha linguagem denotam os limites de meu mundo". A Igreja não é um gueto. Sua missão fundamental é anunciar a Boa Notícia ao homem hodierno. Ao imperativo de Jesus "ide por todo o mundo, proclamai o Evangelho a toda criatura" $(M c 16,15)$, corresponde a necessidade de falar uma linguagem compatível ao entendimento da pessoa humana contemporânea, ou do contrário, corre-se o risco de não haver comunicação. A Palavra de Deus revela a natureza dialogal da Revelação $(D V 2)$, em que Deus, por livre decisão de sua vontade, revela-se a si mesmo e se dá a conhecer aos homens.

Deus fala e vem ao encontro do homem, dando-se a conhecer no diálogo. [...] Todo homem aparece como destinatário da Palavra, interpelado e chamado a entrar, por uma resposta livre, em tal diálogo de amor. [...] O homem é criado na Palavra e vive nela; e não se pode compreender a si mesmo, se não se abre a este diálogo (VD 22).

É no diálogo com Deus que se encontra resposta para as perguntas mais profundas que habitam no coração humano. "Só Deus responde à sede que está no coração de cada homem!" (VD 23). Só em Deus nos compreendemos a nós mesmos. "A Palavra de Deus revela que toda existência do homem está sob o chamamento divino" (VD 25). Pela palavra humana chega até às pessoas a Palavra de Deus. "Deus se comunica ao homem através de vários sinais. Entre eles, a palavra é o sinal por excelência que presentifica Deus entre os homens" 39 . Deus fala por meio do homem, à maneira dos homens, pois onde o emissor usa um código desconhecido pelo receptor, não acontece comunicação. Deus fala ao homem em linguagem humana através dos homens, e o homem é convidado a responder pela fé. Deus serve-se de sinais para falar, pois se falasse à maneira divina não seria compreendido. A palavra humana torna-se sacramento da ação de Deus no momento atual da vida. Deus atua no acontecimento global da comunicação humana.

Deus se comunica em palavras humanas. Esse é o meio onde Deus se revela. À luz da fé, a palavra é o lugar de acesso a Deus. Pela palavra, a presença e o ser de Deus se tornam atuais aqui e agora. Deus manifesta-se na palavra humana como o Deus conosco. $\mathrm{O}$ anúncio da

${ }^{39}$ MOESCH, O. A Palavra de Deus, p. 23. 
Palavra de Deus se dá através da palavra humana. Para se comunicar, Deus se serve da voz e da maneira de ser do evangelizador. A fé em Jesus Cristo chega até o ser humano através de pessoas concretas. Por isso, pela sua maneira de ser, o evangelizador se torna um sinal de Deus.

Cada modalidade de anúncio tenha presente a relação intrínseca entre comunicação da Palavra de Deus e testemunho cristão; disso depende a própria credibilidade do anúncio. [...] É indispensável dar, com o testemunho, credibilidade a esta Palavra, para que não apareça como uma bela filosofia ou utopia, mas antes como uma realidade que se pode viver e que faz viver. Esta reciprocidade entre Palavra e testemunho recorda o modo como o próprio Deus se comunicou por meio da encarnação do seu Verbo. A Palavra de Deus alcança os homens através do encontro com testemunhas que a tornam presente e viva. [...] O testemunho cristão comunica a Palavra atestada nas Escrituras. Por sua vez, as Escrituras explicam o testemunho que os cristãos são chamados a dar com a própria vida (VD 97).

É necessário traduzir em gestos de amor a Palavra escutada, para que o Evangelho se torne credível. O amor ao próximo, radicado no amor a Deus como compromisso, torna-se, também, meio de anúncio de Jesus Cristo, que passou fazendo o bem (cf. At 10,38). O evangelizador deve ser um testemunho do amor de Deus aos homens. "A Palavra divina deve ressoar" (VD 113) através do testemunho credível do evangelizador, pois não há separação entre o que Deus diz e faz. Deus age na história da salvação e na vida pessoal de cada pessoa. A Palavra de Deus é atual, "é viva e eficaz" ( $H b 4,12)$, tem caráter performativo ( $V D$ 53), leva o ouvinte a modificar a sua práxis. Sua finalidade é a metanóia, pela ampliação da cosmovisão, para contemplar mais largamente o horizonte do Reino de Deus, e sua irrupção no "já e ainda-não" escatológico. Enquanto paráclase, exorta, apela e adverte à decisão pessoal. A partir de um indicativo, formula um imperativo. Não só manifesta a sua força ilocucionária, presentificando o evento Cristo aqui e agora, mas também opera perlocucionariamente, como um apelo a viver o que se prega.

A Palavra de Deus é fonte da vida da Igreja. A Igreja é assembleia dos que crêem em Jesus Cristo, é communio fidelium. "A Igreja funda-se sobre a Palavra de Deus, nasce e vive dela" (VD 3). A fé vem do ouvir a Palavra de Deus (cf. $R m$ 10,17) e atua na caridade (cf. 1 Cor 13). Anúncio explícito e testemunho constituem a base da pregação 
que chama à conversão e forma comunidade. A pregação deve ser acompanhada pelo testemunho da própria vida. As ações não devem desmentir as palavras.

A pregação é uma atividade comunicacional pela qual Deus servese de sinais para falar em uma situação concreta com suas circunstâncias determinadas. Pela pregação deve acontecer uma "atualização da mensagem da Sagrada Escritura, de tal modo que os fiéis sejam levados a descobrir a presença e a eficácia da Palavra de Deus no momento atual da sua vida" (VD 59). É preciso anunciar a Palavra de Deus aos homens de hoje. Atualizar, traduzir, converter, esmiuçar essa Boa Nova para uma linguagem hodierna, compreensível.

A Palavra de Deus é regra suprema da fé ( $D V$ 21). A Igreja "é uma comunidade que escuta e anuncia a Palavra de Deus. A Igreja não vive de si mesma, mas do Evangelho; e do Evangelho tira sem cessar, orientação para o seu caminho. Só quem se coloca primeiro à escuta da Palavra é que pode depois tornar-se seu anunciador" (VD 51). Escutar para depois anunciar. "É preciso que os pregadores tenham familiaridade e contato assíduo com o texto sagrado" (VD 59; cf. DV 25). Como pregar com convicção sem antes escutar, acolher, celebrar e viver a Palavra de Deus? Urge estar sempre pronto a dar a razão da própria esperança a todo aquele que a pedir (cf. $1 P d 3,15$ ).

A evangelização deve seguir a dinâmica do Verbo encarnado, sacramento do Pai, que manifestou e realizou o inefável mistério de Deus de forma humana e sensível, na história. "Deus não se revela ao homem abstratamente, mas assumindo linguagens, imagens e expressões ligadas às diversas culturas" (VD 109). A Palavra de Deus tem uma capacidade intrínseca de atingir todas as pessoas humanas no contexto cultural onde vivem, e "de penetrar e exprimir-se em culturas e línguas diferentes" (VD 116). Deus quer se comunicar com todos os homens onde quer que estes se encontrem. "A Palavra divina não cessa de nos interpelar pessoalmente aqui e agora" (VD 122). Deus continua a chamar ouvintes e anunciadores convictos e persuadidos de sua Palavra.

\subsection{A linguagem da evangelização a partir da Evangelii Nuntiandi e da Evangelii Gaudium}

A grande missão da Igreja consiste em evangelizar, o que "constitui, de fato, a graça e a vocação própria da Igreja, a sua mais profunda identidade" (EN 14). Pelo anúncio do Evangelho, a Igreja confere sentido à vida humana, pois "uma vida sem fé e sem perspectivas de 
grande fôlego não vale a pena de ser vivida". ${ }^{40}$ Enquanto instrumento de salvação, a Igreja está a serviço do mundo em sua integralidade, com a pretensão de "atingir a totalidade do homem" engajamento em prol de uma sociedade mais fraterna, pautada pela fé cristã, que é um dom inestimável de Deus para os homens. "A missão eclesial está a serviço da vida plena". ${ }^{42}$ A Igreja vive e comunica a vida nova em Cristo, que "atinge o ser humano por inteiro e desenvolve em plenitude a existência humana" ( $D A p$ 356). A Igreja está a serviço da vida plena quando evangeliza.

Palavras comoventes somadas a um testemunho credível de santidade constituem um atrativo eficaz para a ação evangelizadora da Igreja. "Hoje só convence uma 'fé vivida', ou seja, a fé só pode testemunhar e não demonstrar." 43 Os cristãos precisam dar um testemunho decidido da própria fé, pois "o homem contemporâneo escuta com melhor boa vontade as testemunhas do que os mestres" ( $E N$ 41). O anúncio que não vem acompanhado pelo testemunho torna-se vazio de significado. A pedagogia do testemunho, como verdadeira ação evangelizadora, toma como ponto de partida o outro ${ }^{44}$, cultivando uma sensibilidade face às suas necessidades.

O grande desafio da Igreja consiste na missão de anunciar com competência a Boa Nova de Cristo: "Ide, portanto, e fazei que todas as nações se tornem discípulos" (Mt 28,19). A Igreja se redescobre "em saída" da própria comodidade para alcançar as periferias existenciais, na "dinâmica do êxodo e do dom" (EG 21), sem medo, em todos os lugares, procurando os afastados, sem "reações lastimosas ou alarmistas" (EG 24) perante as dificuldades. "A transmissão da fé nunca foi um trabalho simples, mas, nestes tempos de mudança, o desafio é ainda maior." ${ }^{45}$ Toda a renovação missionária da Igreja depende da fidelidade à sua vocação originária e necessita de ousadia e criatividade.

É fundamental evangelizar com inteligência. "No mundo atual, com a velocidade das comunicações e a seleção interessada dos conteúdos feita pelos meios de comunicação social, a mensagem que anunciamos corre mais do que nunca o risco de aparecer mutilada e reduzida a

\footnotetext{
${ }^{40}$ GRINGS, D. A Igreja de Cristo para o terceiro milênio, p. 49.

${ }^{41}$ PIEPKE, J. G. A Igreja voltada para o homem, 131.

${ }^{42}$ GOMES, T. F. A eclesiologia conciliar na América Latina, p. 67.

${ }^{43}$ GRINGS, D. A evangelização da cidade, p. 150.

${ }^{44}$ Cf. BRIGHENTI, A. A missão evangelizadora no contexto atual, p. 5.

${ }^{45}$ BERGOGLIO, J. M. Anunciar o Evangelho, p. 61.
} 
alguns aspectos secundários" (EG 34). Não se pode supor que todos os interlocutores estejam no mesmo horizonte de compreensão daquilo que é dito. É urgente um anúncio bem articulado dos conteúdos essenciais da fé que exprimam "mais diretamente o coração do Evangelho" (EG 36), e que leve em consideração "a totalidade harmoniosa da mensagem cristã" ( $E G$ 39). A teologia, auxiliada por outras ciências, ajuda a amadurecer o juízo eclesial na interpretação e no anúncio da mensagem evangélica, para que haja fidelidade não só na formulação das verdades da fé, mas também na sua transmissão às pessoas de hoje. É preciso levar em consideração não apenas o conteúdo, mas também a forma como anunciamos para evangelizarmos com eficácia.

O mundo atual, marcado pelo conhecimento técnico e pela informação, lança alguns desafios para a evangelização, em um contexto de progresso científico e inovações tecnológicas com aplicações diversas em nossa vida. É possível perceber que há uma crise antropológica em uma economia de exclusão e de desigualdade social, onde impera a cultura do descartável e da "globalização da indiferença" ( $E G 54)$. Estamos anestesiados pelo bem-estar. "A ambição do poder e do ter não conhece limites" ( $E G 56)$ no âmbito do mercado divinizado, onde "os mecanismos da economia atual promovem uma exacerbação do consumo" (EG 60), criando uma mentalidade adversa a um desenvolvimento sustentável.

Se está sob o reinado da exterioridade, da imediatez, da visibilidade, da superficialidade e da provisoriedade, no qual se busca respostas instantâneas para problemas complexos. "A globalização comportou uma acelerada deterioração das raízes culturais" ( $E G$ 62), conduzindo a uma relatividade na criteriologia moral e a uma privatização da prática de fé. Isso gera uma aguda "crise de identidade e um declínio do fervor" ( $E G$ 78). Nesse sentido, é necessária uma evangelização comprometedora "que suscite os valores fundamentais" (EG 74) e supere um "mundanismo espiritual" ( $E G$ 93) egoísta, subjetivista, individualista, narcisista e imanentista. "O testemunho de comunidades autenticamente fraternas e reconciliadas, isso é sempre uma luz que atrai" ( $E G 100)$. Urge renovar em cada cristão o apelo primordial ao testemunho de comunhão fraterna como a sua identidade fundamental.

Todo batizado, membro do povo de Deus, é chamado a crescer como evangelizador para dar as razões da sua esperança àqueles que necessitam (cf. 1 Pd 3,15), superando a mediocridade. "Ser discípulo significa ter a disposição permanente de levar aos outros o amor de 
Jesus" ( $E G$ 127), deixando-se conduzir pelo mesmo "Espírito que inspirou os Evangelhos e atua no povo de Deus" (EG 139), para proferir o anúncio explícito que confere fervor e significado à vida, pois "a fé vem da pregação" $(R m 10,17)$, visto que a palavra humana é mediadora do diálogo entre Deus e o seu povo.

Um grande desafio da pregação consiste em "transmitir a síntese da mensagem evangélica" ( $E G$ 143). Para isso, é preciso dedicar um tempo privilegiado de estudo, oração, reflexão e criatividade, desenvolvendo uma familiaridade com a Palavra, para que se consiga reter a mensagem central de um texto, tentando entender o que o escritor sagrado pretendia exprimir. É fundamental "se aproximar da Palavra com o coração dócil e orante" (EG 149), para deixar-se transformar por ela ${ }^{46}$. "A boca fala daquilo de que o coração está cheio" (Mt 12,34). Antes de pregar é preciso amar a Palavra que se prega. "A Igreja não evangeliza, se não se deixa continuamente evangelizar" (EG 174). É necessário formar-se constantemente na escuta da Palavra de Deus, pois ela é o coração da evangelização.

O pregador deve descobrir o que as pessoas precisam ouvir, respondendo a problemas e questionamentos reais e não fictícios. "Nunca se deve responder a perguntas que ninguém se põe" (EG 155). É interessante exercitar uma sensibilidade contemplativa para ler nos acontecimentos cotidianos a mensagem que Deus nos quer transmitir. Além disso, é preciso apresentar a mensagem cristã de forma adequada, com linguagem simples, clara, direta e adaptada, com uma lógica de desenvolvimento das ideias facilmente captável pelos interlocutores. Uma boa pregação deve conter "uma ideia, um sentimento, uma imagem" ( $E G$ 157) para tornar a mensagem próxima da vida, como algo que soa familiar ${ }^{47}$. Também é interessante utilizar uma linguagem positiva e propositiva, que responda a um apelo integral e ofereça esperança e perspectiva de futuro.

\subsection{Buscar a unidade na diversidade}

Não se pode compreender a unidade como uniformidade ou como anulação das diferenças individuais. $\mathrm{O}$ centro da unidade está no respeito

\footnotetext{
${ }^{46}$ No dizer de Geffré: “Toda leitura importante me transforma.” (GEFFRÉ, C. op. cit., p. 45).

${ }^{47}$ Como afirma Geffré: "Não há transmissão da fé sem reinterpretação do evento Jesus Cristo." (Ibid., p. 42). Sobre o mesmo assunto escreve Urbano Zilles: "O pregador deve fazer uma leitura atual dos testemunhos bíblicos" (ZILLES, U. Teologia da pregação, p. 31), traduzindo a Palavra de Deus para dentro da situação concreta do ouvinte.
} 
e na consideração da diferença e pela capacidade de convivência. A diversidade e a variedade enriquecem a humanidade. A humanização é um processo que passa pela convivência. A abertura ao outro amplia horizontes de compreensão e de sentido. A fé cristã ensina que o sentido maior da vida é o amor a Deus e ao próximo, e que tudo deve convergir para esse fim. A Igreja é una e universal; é sacramento de unidade. A missão da Igreja, que consiste em levar a mensagem de Cristo a todos os povos, é uma missão ecumênica, pois se destina a toda a humanidade,

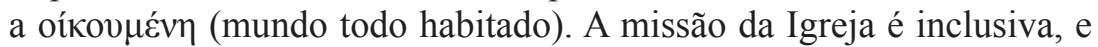
constitui-se em um grande esforço para agregar a Cristo "os filhos de Deus dispersos" (Jo 11,52).

Cristo chama todos os cristãos à unidade, disso deriva o imperativo: "que todos sejam um para que o mundo creia" (Jo 17,21). Deus deseja uma comunhão viva. "A vontade de Deus é a unidade de toda a humanidade dispersa" (UUS 6). Os obstáculos à unidade surgem do pecado humano que gera divisões e desvirtua dos caminhos de Deus. "As divisões dos cristãos impedem a Igreja de realizar a plenitude de catolicidade" (UR 4). A tarefa da unidade é sempre frágil enquanto depende dos cristãos. Porém, é preciso cultivar a esperança na ação do Espírito, que sopra onde quer, remove os empecilhos e transforma os corações. $\mathrm{O}$ mistério da unidade da Igreja tem como supremo modelo e princípio a unidade de um só Deus Uno e Trino. A reintegração da unidade é dom e tarefa. A unidade é obra do Espírito, é dom de Deus, que requer a colaboração humana como resposta. Por isso, é preciso orar e trabalhar em prol da unidade dos cristãos para não se perder a credibilidade do testemunho, pois "Cristo Senhor fundou uma só e única Igreja. [...] Esta divisão, porém, contradiz abertamente a vontade de Cristo, e é escândalo para o mundo" (UR 1). A fé cristã leva a viver a comunhão com Deus e com o próximo.

É fundamental o diálogo na busca da unidade, para que haja "um conhecimento mais verdadeiro e um apreço mais justo da doutrina e da vida de cada Comunhão [...] em vista do bem comum [...] para promover a equidade e a verdade, a concórdia e a colaboração, o espírito fraterno e a união" (UR 4). Para poder amar, é preciso conhecer o outro. O diálogo ecumênico deve ser exercido com compreensão e com conhecimento de causa, com o objetivo de encontrar entendimento. Nesse sentido, deve-se "proceder com amor pela verdade, com carinho e humildade" (UR 11). É preciso guardar a unidade nas coisas necessárias, conservar a devida liberdade no que é secundário, mas, sobretudo, cultivar a caridade, para 
que se manifesta mais claramente o sentido da catolicidade da Igreja. A restauração da unidade provoca a renovação da própria vocação da Igreja, maior fidelidade à sua vocação, o que exige um esforço perene de reforma e de "conversão interior" (UR 7). É fundamental algumas atitudes, tais como sinceridade e transparência.

Sem o conhecimento e a estima do outro, pode-se cair no risco das divisões. É fato que, desde a Igreja antiga, a "falta de mútua compreensão e caridade, deu ocasião às separações" (UR 14). O Concílio Vaticano II nutre "a esperança de que cresça pouco a pouco em todos o sentido ecumênico e a estima mútua" (UR 19). A Palavra de Deus produz em o desejo e o "propósito de reconciliar todos os cristãos na unidade" (UR 24), para que o Espírito Santo habite nos corações e Deus seja tudo em todos.

Há muitos elementos de santificação e de verdade que se encontram fora dos limites visíveis da Igreja Católica. "O ecumenismo busca precisamente fazer crescer a comunhão parcial existente entre os cristãos até à plena comunhão na verdade e na caridade" (UUS 14). Os dons pertencentes à Igreja de Cristo, presentes em outras comunidades cristãs, impelem para a unidade católica. No caminho rumo à unidade, faz-se necessário a conversão interior, do coração, que cresce na medida da fidelidade ao Evangelho. "Há um nexo claro entre renovação, conversão e reforma" (UUS 16). Como a Igreja é peregrina, ela é chamada a uma perene reforma. Este é um apelo a que nenhuma comunidade humana pode escusar-se. "A progressiva comunhão numa contínua reforma" (UUS 17) é um dos traços fundamentais do ecumenismo, respeitando o conteúdo integral da fé revelada, pois a reconciliação não pode acontecer à custa da verdade. A verdade da fé, embora tenha um significado imutável, pode ser expressa de modo multiforme, sendo traduzida nas diversas culturas.

A alma da busca pela unidade é a conversão do coração e a santidade de vida. O amor a Deus e ao próximo é o artífice da comunhão. "Se nos amamos, tendemos a aprofundar a nossa comunhão, a orientá-la para a perfeição" (UUS 21). O amor é o vínculo da unidade que se nutre na oração. "Quando os cristãos rezam juntos, a meta da unidade fica mais próxima" (UUS 22), pois a fonte da unidade é o próprio Deus, e somente com Ele, são superadas as múltiplas fragmentações e divisões que marcaram a história do cristianismo. A oração ecumênica dá força e credibilidade à missão cristã e é "fonte de iluminação acerca da verdade" (UUS 70). 
O diálogo supõe vontade de reconciliação e de superação das diferenças recíprocas, em vista da unidade na verdade. "O diálogo ecumênico tem o caráter de uma procura comum da verdade" (UUS 33). A verdade forma e orienta as consciências para a unidade. A sinergia entre oração e diálogo torna mais fecundo o movimento ecumênico. A humildade ajuda a reconhecer a necessidade de conversão para superar as divisões e consolidar a unidade. A partir de um diálogo de conversão, estabelece-se um diálogo de salvação. O diálogo é um "instrumento natural para confrontar os diversos pontos de vista e, sobretudo, examinar aquelas divergências que são obstáculo à plena comunhão dos cristãos entre si" (UUS 36). É preciso expor com clareza, lealdade e correção a própria doutrina, para resolver os questionamentos mais sérios e nevrálgicos, considerando os horizontes de sentido e as categorias de compreensão de cada comunidade eclesial, sem perder de vista a experiência histórica concreta do outro. Um grande avanço é a ênfase na pertença comum a Cristo através do uso de "vocabulários mais orientados a ressaltar a profundidade da comunhão" (UUS 42).

É preciso estimar aquilo que nos une e reconhecer "os bens verdadeiramente cristãos, oriundos de um patrimônio comum" (UUS 47). A procura da unidade é inerente à fé cristã. "A legítima diversidade não se opõe de forma alguma à unidade da Igreja, antes aumenta o seu decoro e contribui significativamente para o cumprimento da sua missão" (UUS 50). É preciso alimentar, com toda a certeza, a "unidade na legítima diversidade" (UUS 54). E na medida do possível, "o intercâmbio de dons entre as Igrejas, na sua complementaridade, torna fecunda a comunhão" (UUS 57). Baseando-se sobre aquilo que temos em comum, devemos nos empenhar na busca da unidade, respeitando as diferenças, superando as discrepâncias, exercitando o perdão mútuo, para dar ao mundo um testemunho eloquente da mesma fé em Cristo. "A finalidade última do movimento ecumênico é o restabelecimento da plena unidade visível de todos os batizados" (UUS 77). Essa é uma questão de coerência evangélica que afeta a todos os que foram regenerados em Cristo, pois "acreditar em Cristo significar querer a unidade" (UUS 9).

A única Igreja de Cristo subsiste na Igreja Católica, onde está presente a plenitude dos instrumentos de salvação. "A plena unidade realizar-se-á quando todos participarem da plenitude dos meios de salvação que Cristo confiou à sua Igreja" (UUS 86). A meta é a comunhão plena e visível, que tem na pessoa do Bispo de Roma, o vínculo da unidade e da comunhão entre todas as Igrejas, pois "ele é o 
primeiro entre os servidores da unidade" (UUS 94). O primado do Bispo de Roma tem como função a unidade, e é um requisito essencial para a plena comunhão visível.

Como evangelizadores, os cristãos precisam testemunhar ao mundo não uma imagem de homens divididos por litígios que nada edificam, mas devem empreender uma busca comum, sincera e desinteressada pela verdade. A divisão dos cristãos afeta o anúncio do Evangelho da reconciliação. Não podemos mais admitir "o grave obstáculo que a divisão representa para o anúncio do Evangelho" (UUS 98). Todos os fiéis são convidados a fazer o possível para recompor os laços de união entre todos os cristãos. É importante que "cresça a colaboração entre os discípulos de Cristo" (UUS 101) na solicitude pela restauração da unidade.

\section{Referências}

ALBERIGO, Giuseppe. Transizione epocale: studi sul Concilio Vaticano II. Bologna: Società editrice il Molino, 2009.

BENTO XVI. Exortação Apostólica Pós-Sinodal Verbum Domini: sobre a Palavra de Deus na vida e na missão da Igreja. São Paulo: Paulinas, 2010 (A Voz do Papa, 194).

BEOZZO, José Oscar. Presença e atuação dos bispos brasileiros no Vaticano II. In: GONÇALVES, Paulo Sérgio Lopes; BOMBONATTO, Vera Ivanise (Orgs.). Concílio Vaticano II: análise e prospectivas. 2. ed. São Paulo: Paulinas, 2005. (Alternativas).

BERGOGLIO, Jorge Mario. Anunciar o Evangelho: mensagens aos catequistas. Trad. R. Gurgel. Campinas: Ecclesiae, 2013.

BÍBLIA. Português. A Bíblia de Jerusalém. Nova edição rev. e ampl. São Paulo: Paulus, 2002.

BRIGHENTI, Agenor. A missão evangelizadora no contexto atual: realidade e desafios a partir da América Latina. São Paulo: Paulinas, 2006. (Sinais dos Tempos).

BROWN, Raymond. E.; FITZMYER, Joseph. A.; MURPHY, Roland. E. (Eds.). Novo comentário bíblico São Jerônimo: Novo Testamento e artigos sistemáticos. Trad. Celso Eronides Fernandes. Santo André: Academia Cristã; São Paulo: Paulus, 2011.

COMBLIN, José. Atos dos Apóstolos. Vol. 1. Petrópolis: Vozes, 1988. (Comentário Bíblico).

CONCÍLIO ECUMÊNICO VATICANO II. Constituição Dogmática Dei Verbum: sobre a Revelação Divina. In: DOCUMENTOS DO CONCÍLIO ECUMÊNICO VATICANO II (1962-1965). 4. ed. Trad. Tipografia Poliglota Vaticana. São Paulo: Paulus, 2007. (Documentos da Igreja). 
CONCÍLIO ECUMÊNICO VATICANO II. Constituição Dogmática Lumen Gentium: sobre a Igreja. In: DOCUMENTOS DO CONCÍLIO ECUMÊNICO VATICANO II (1962-1965). 4. ed. Trad. Tipografia Poliglota Vaticana. São Paulo: Paulus, 2007. (Documentos da Igreja).

. Constituição Pastoral Gaudium et Spes: sobre a Igreja no mundo de hoje. In: DOCUMENTOS DO CONCÍLIO ECUMÊNICO VATICANO II (1962-1965). 4. ed. Trad. Tipografia Poliglota Vaticana. São Paulo: Paulus, 2007. (Documentos da Igreja).

. Decreto Unitatis Redintegratio: sobre o ecumenismo. In: DOCUMENTOS DO CONCÍLIO ECUMÊNICO VATICANO II (1962-1965). 4. ed. Trad. Tipografia Poliglota Vaticana. São Paulo: Paulus, 2007. (Documentos da Igreja).

EVANGELHOS E ATOS DOS APÓSTOLOS: Novíssima tradução dos originais. Trad. Cássio Murilo Dias da Silva; Irineu J. Rabuske. São Paulo: Loyola, 2011.

FRANCISCO. Exortação Apostólica Evangelii Gaudium: sobre o anúncio do Evangelho no mundo atual. São Paulo: Paulinas, 2013. (A Voz do Papa, 198).

GEFFRÉ, Claude. Crer e interpretar: a virada hermenêutica da teologia. Trad. L. M. E. Orth. Petrópolis: Vozes, 2004.

GOMES, Tiago de Fraga. A eclesiologia conciliar na América Latina: a comunhão gera a missão. Porto Alegre: Editora Fi, 2015. (Teologia em Diálogo, 1).

. Hermenêutica teológica e teologia da revelação em Claude Geffré. In: SUSIN, Luiz Carlos; RODRIGUES, Jéferson Ferreira (Orgs.). Fazer teológico. Porto Alegre: Editora Fi, 2015. (Teologia em Diálogo, 2).

GRINGS, Dadeus. A evangelização da cidade: o apostolado urbano. Porto Alegre: Edipucrs, 2004.

. A Igreja de Cristo para o terceiro milênio. Porto Alegre: Edipucrs, 1997. (Teologia, 10).

HACKMANN, Geraldo Luis Borges. A Igreja da Lumen Gentium e a Igreja da Gaudium et Spes. Teocomunicação, Porto Alegre, v. 35, n. 150, p. 657-676, dez. 2005.

. A Igreja nos Atos dos Apóstolos. Teocomunicação, Porto Alegre, v. 31, n. 133, p. 427-459, set. 2001.

HAMMAN, Adalbert-Gautier. A vida cotidiana dos primeiros cristãos (95-197). Trad. B. Lemos. São Paulo: Paulus, 1997. (Patrologia).

INICIAÇÃO À BÍBLIA. Para você estudar o Novo Testamento. Vol. 2. Trad. A. Cunha. São Paulo: Paulinas, 1981.

JOÃO PAULO II. Carta Encíclica Ut Unum Sint: sobre o empenho ecumênico. In: ENCÍCLICAS DE JOÃO PAULO II (1978-1995). Org. L. Costa. Trad. Tipografia Poliglota Vaticana. São Paulo: Paulus, 1997. (Documentos da Igreja).

KASPER, Walter. A Igreja católica: essência, realidade e missão. Trad. N. Schneider. São Leopoldo: Unisinos, 2012. (Theologia Publica). 
KASPER, Walter. Renovación a partir del origen: para la interpretación y recepción del Concilio Vaticano II. In: VIDE, V.; VILLAR, J. R. El Concilio Vaticano II: una perspectiva teológica. Madrid: San Pablo, 2013.

KLOPPENBURG, Boaventura. A Eclesiologia do Vaticano II. Petrópolis: Vozes, 1971.

LIBANIO, João Batista.Concílio Vaticano II: em busca de uma primeira compreensão. São Paulo: Loyola, 2005. (Theologica, 14).

MADRIGAL, Santiago. Vaticano II: remembranza y actualización, esquemas para una eclesiología. Santander: Sal Terrae, 2002.

MARGUERAT, Daniel. Os Atos dos Apóstolos. In: MARGUERAT, Daniel (Org.). Novo Testamento: história, escritura e teologia. Trad. M. Oliva. São Paulo: Loyola, 2009.

MOESCH, Olavo. A Palavra de Deus: teologia e práxis da evangelização. Colaboração de de Ceverino. Craco e Marcos André. Balbinot. Petrópolis: Vozes, 1995.

MOSCONI, Luis. Atos dos Apóstolos: como ser Igreja no início do terceiro milênio? 4. ed. São Paulo: Paulinas, 2005.

PAULO VI. Exortação Apostólica Evangelii Nuntiandi: sobre a evangelização no mundo contemporâneo. 20. ed. São Paulo: Paulinas, 2008. (A Voz do Papa, 85).

PIEPKE, Joaquim G. A Igreja voltada para o homem: Eclesiologia do Povo de Deus no Brasil. Trad. F. Dattler. São Paulo: Ed. Paulinas, 1989. (Fermento na Massa).

RATZINGER, Joseph. Os apóstolos e os primeiros discipulos de Cristo. Trad. G. B. Grosso. São Paulo: Planeta, 2010.

SANTOS, Manoel Augusto. Quarenta anos depois do Concílio Vaticano II. In: SANTOS, Manoel Augusto (Org.). Concílio Vaticano II: quarenta anos da Lumen Gentium. Porto Alegre: Edipucrs, 2005 (Teologia, 27).

SOUZA, Luiz Alberto Goméz. Do Vaticano II a um novo Concílio? O olhar de um cristão leigo sobre a Igreja. São Paulo: Loyola; Goiás: Rede Paz, 2004 (Ceris).

SOUZA, N. Contexto e desenvolvimento histórico do Concílio Vaticano II. In: GONÇALVES, Paulo Sérgio Lopes; BOMBONATTO, Vera Ivanise (Orgs.). Concílio Vaticano II: análise e prospectivas. 2. ed. São Paulo: Paulinas, 2005 (Alternativas).

STOTT, John Robert Walmsley. A mensagem de Atos: até os confins da terra. Trad. M. A. Hediger; L. Yamakami. Leicester: Abu, 1994 (A Bíblia fala hoje).

V CONFERÊNCIA GERAL DO EPISCOPADO LATINO-AMERICANO E DO CARIBE. Documento de Aparecida. 3. ed. Trad. L. A. S. Rossi. Brasília: Ed. CNBB; São Paulo: Paulus, Paulinas, 2007.

WEGNER, Uwe. Exegese do Novo Testamento: manual de metodologia. São Leopoldo: Sinodal; São Paulo: Paulus, 1998.

ZILLES, Urbano. Teologia da pregação. Porto Alegre: Letra e Vida, 2013. 